University of Nebraska - Lincoln

DigitalCommons@University of Nebraska - Lincoln

Publications from USDA-ARS / UNL Faculty

U.S. Department of Agriculture: Agricultural

Research Service, Lincoln, Nebraska

November 1993

\title{
Above-ground vegetative development and growth of winter wheat as influenced by nitrogen and water availability
}

Wallace Wilhelm

University of Nebraska-Lincoln, wwilhelm1@unl.edu

Gregory S. McMaster

USDA-ARS, greg.mcmaster@ars.usda.gov

R. W. Rickman

USDA-ARS

Betty Klepper

USDA-ARS

Follow this and additional works at: https://digitalcommons.unl.edu/usdaarsfacpub

Part of the Agricultural Science Commons

Wilhelm, Wallace; McMaster, Gregory S.; Rickman, R. W.; and Klepper, Betty , "Above-ground vegetative development and growth of winter wheat as influenced by nitrogen and water availability" (1993).

Publications from USDA-ARS / UNL Faculty. 112.

https://digitalcommons.unl.edu/usdaarsfacpub/112

This Article is brought to you for free and open access by the U.S. Department of Agriculture: Agricultural Research Service, Lincoln, Nebraska at DigitalCommons@University of Nebraska - Lincoln. It has been accepted for inclusion in Publications from USDA-ARS / UNL Faculty by an authorized administrator of DigitalCommons@University of Nebraska - Lincoln. 


\title{
Above-ground vegetative development and growth of winter wheat as influenced by nitrogen and water availability
}

\author{
W.W. Wilhelm ${ }^{\text {a }}$, Gregory S. McMaster ${ }^{b}$, \\ R.W. Rickman ${ }^{\mathrm{c}}$ and Betty Klepper ${ }^{\mathrm{c}}$ \\ ${ }^{a}$ USDA-ARS, Department of Agronomy, University of Nebraska-Lincoln, \\ Lincoln, NE 68583-0934, USA \\ ${ }^{b}$ USDA-ARS, Great Plains Systems Research Unit, P.O. Box E, Fort Collins, CO 80522, USA \\ c USDA-ARS, Columbia Plateau Conservation Research Center, P.O. Box 370, \\ Pendleton, OR 97801, USA
}

(Received 22 October 1991; accepted 6 August 1992)

\section{ABSTRACT}

Wilhelm, W.W., McMaster, G.S., Rickman, R.W. and Klepper, B., 1993. Above-ground vegetative development and growth of winter wheat as influenced by nitrogen and water availability. Ecol. Modelling, 68: 183-203.

Assessing the influence of nitrogen and water availability on development and growth of individual organs of winter wheat (Triticum aestivum L.) is critical in evaluating the response of wheat to environmental conditions. We constructed a simulation model (SHOOTGRO 2.0) of shoot vegetative development and growth from planting to early boot by adding nitrogen and water balances and response functions for seedling emergence, tiller and leaf appearance, leaf and internode growth, and leaf and tiller senescence to the existing wheat development and growth model, SHOOTGRO 1.0. Model inputs include daily maximum and minimum air temperature, rainfall, daily photosynthetically active radiation, soil characteristics necessary to compute soil $\mathrm{N}$ and water balances, and several factors describing the cultivar and soil conditions at planting. The model provides information on development and growth characteristics of up to six cohorts of plants within the canopy (cohort groupings are based on time of emergence). The cohort structure allows SHOOTGRO 2.0 to provide output on the frequency of occurrence of plants with specific features (tillers and leaves) within the canopy. The model was constructed so that only water availability limited seedling emergence. Resource availability (nitrogen and water) does not influence time of leaf appearance. Leaf and internode growth, and leaf and tiller senescence processes are limited by the interaction of $\mathrm{N}$ and water availability. Tiller appearance is influenced by the

Correspondence to: W.W. Wilhelm, USDA-ARS, Department of Agronomy, University of Nebraska-Lincoln, Lincoln, Nebraska 68583-0934, USA. 
interaction of $\mathrm{N}$, radiation and water availability. Predicted and observed dates of emergence and appearance of the first tiller had correlation coefficients of 0.98 and 0.93 , respectively. However, these events were, on average, predicted 3.2 and 5.2 days later than observed. SHOOTGRO 2.0 generally under-predicted the number of culms per unit land area, partially because the simulation is limited to a maximum of 16 culms/plant. Model output shows that the simulation is sensitive to $\mathrm{N}$ and water inputs. The model provides a tool for predicting vegetative development and growth of the winter wheat with individual culms identified and followed from emergence through boot. SHOOTGRO 2.0 can be used in evaluating alternative crop management strategies.

\section{INTRODUCTION}

Most research evaluating wheat (Triticum aestivum L.) growth and yield responses to $\mathrm{N}$ (e.g. Brown, 1971; Campbell et al., 1977a,b) and water (Brown, 1971; Hooker et al., 1983) have been conducted during reproductive growth stages. Because of the overall interest in grain yield, much less effort has focused on development and growth responses of wheat to $\mathrm{N}$ and water availability during vegetative development. However, vegetative development has a significant impact on grain yield potential.

Events during the vegetative development phase can impact grain yield potential through modification of spike numbers per unit land area (Brocklehurst et al., 1978; Sionit et al., 1980; Hooker et al., 1983) and leaf area development and duration (Evans et al., 1975). Events influencing spike number include seed germination, seedling emergence (Hunter and Erickson, 1952), and tiller initiation and survival (Hooker et al., 1983). These processes, with the exception of germination, are sensitive to nitrogen (N) and water availability (Greenwood, 1976).

Recently we developed a model (SHOOTGRO 1.0; McMaster et al., 1991) which systematically combined current knowledge of above-ground vegetative development and growth of winter wheat in the absence of environmental stress. SHOOTGRO 1.0 simulates seedling emergence and appearance of tillers, leaves and internodes, based on the accumulation of thermal time [growing degree-days (GDD)], for several cohorts of plants (cohort groupings based on time of seedling emergence). The phyllochron (developmental time between the appearance of successive main stem leaves) is calculated from the change in day length at emergence (Baker et al., 1980). Leaf growth is defined as an exponential function of leaf number and linear function of thermal time, with higher order tillers having digressively smaller leaf sizes. Internode elongation proceeds as a linear function of thermal time with maximum potential internode length a power function of internode number. Simulations stop at early boot, immediately before the beginning of peduncle elongation. 
The purpose of the SHOOTGRO model is to incorporate current knowledge of above-ground vegetative development and growth of winter wheat into a simulation package which has greater detail on the structure and morphological characteristics of the canopy than provided by existing wheat models. The purpose of this paper is to report our continuing effort to improve SHOOTGRO by developing SHOOTGRO 2.0, making the simulation sensitive to available $\mathrm{N}$ and water.

\section{MODEL DESCRIPTION}

SHOOTGRO 2.0, a simulation of vegetative development and growth of winter wheat as affected by $\mathrm{N}$, photosynthetically active radiation (PAR) and water availability, is divided into several submodels (Fig. 1). SHOOTGRO 2.0 modifies and extends SHOOTGRO 1.0 (McMaster et al., 1991). Most modifications relate to the addition of soil $\mathrm{N}$ and water budget routines and the addition of response functions for crop development and growth to availability of $\mathrm{N}$ and water resources. SHOOTGRO 2.0 simulates time of appearance and senescence and size of each potential culm and node unit (node, leaf blade, leaf sheath and internode) on a plant. The fraction of plants with each tiller is a function of N, PAR and water availability, and is calculated as the simulation proceeds.

Nitrogen (NITBAL; Godwin and Vlek, 1985) and water (WATBAL; Ritchie, 1972) balance subroutines from CERES-Wheat (Ritchie, 1985)

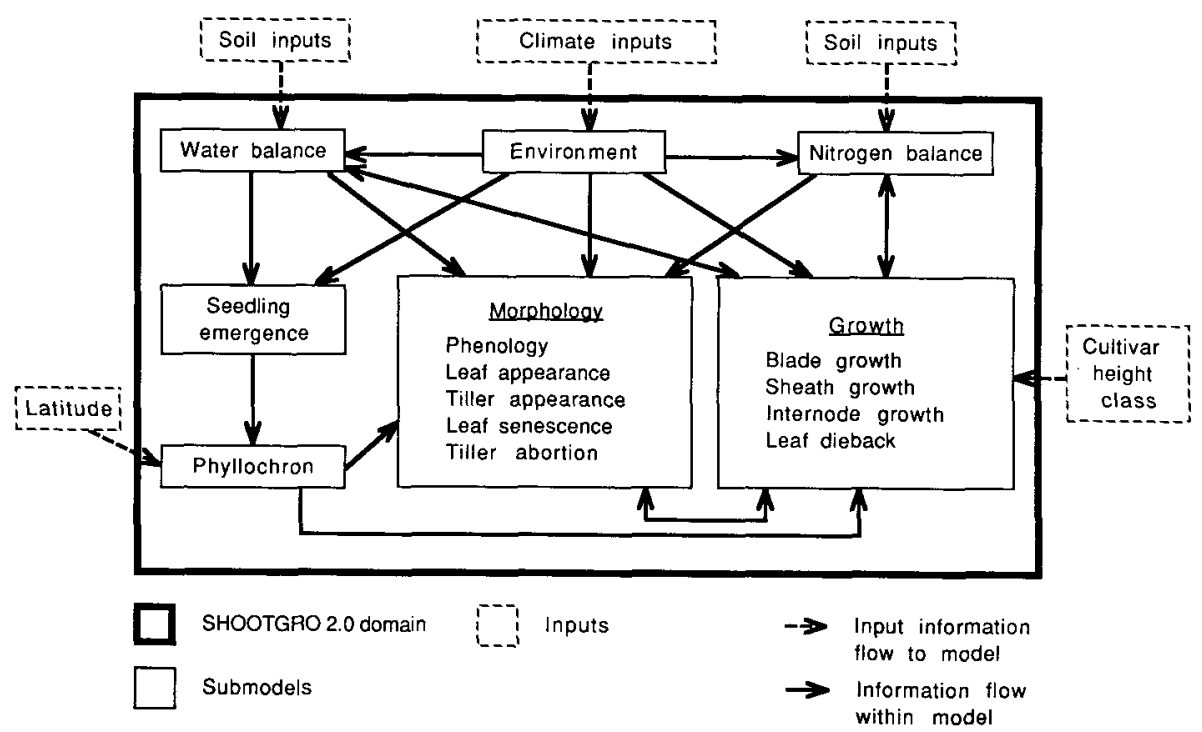

Fig. 1. Conceptual diagram of submodels and flow of information in SHOOTGRO 2.0. 
TABLE 1

Comparison of major input parameters between SHOOTGRO 1.0 and 2.0

\begin{tabular}{lllll}
\hline Name & Symbol & Units & \multicolumn{2}{c}{ SHOOTGRO } \\
\cline { 4 - 5 } & & & 1.0 & 2.0 \\
\hline Planting depth & PDEPTH & $\mathrm{cm}$ & $\times$ & $\times$ \\
Planting date & PDATE & - & $\times$ & $\times$ \\
Latitude & LAT & degrees, minutes & $\times$ & $\times$ \\
Initial seedbed conditions & CONDIT & - & $\times$ & $\times$ \\
Upper limit of stage 1 drying & U & $\mathrm{mm}$ & \\
Soil albedo & SALB & - & & $\times$ \\
Soil conductivity constant & SWCON & $\mathrm{day}^{-1}$ & $\times$ \\
SCS runoff curve number & CN2 & - & & $\times$ \\
C: N of residue & SCN & $\mathrm{kg} \mathrm{C} \mathrm{kg} \mathrm{N}^{-1}$ & \\
Dry weight of surface residue & STRAW & $\mathrm{kg} \mathrm{ha}^{-1}$ & $\times$ \\
Dry weight of root residue & ROOT & $\mathrm{kg} \mathrm{ha}^{-1}$ & \\
Depth of residue incorporation & SDEP & $\mathrm{cm}^{-1}$ & \\
Bulk density & BD & $\mathrm{g} \mathrm{cm}^{-3}$ & $\times$ \\
Organic carbon & OC & $\%$ & & $\times$ \\
Initial soil water & SW & $\mathrm{m}^{3} \mathrm{~m}^{-3}$ & $\times$ \\
pH of soil & PH & - & & $\times$ \\
Nitrate-N concentration & NO3 & $\mathrm{mg} \mathrm{N} \mathrm{kg}^{-1}$ & \\
Ammonium-N concentration & NH4 & $\mathrm{mg} \mathrm{N} \mathrm{kg}^{-1}$ & \\
Thickness of soil layers & DLAYR & $\mathrm{cm}^{-1}$ & $\times$ \\
Soil saturation constant & KTERM & - & \\
\% sand & SAND & $\%$ & $\times$ \\
$\%$ silt & SILT & $\%$ & $\times$ \\
$\%$ clay & CLAY & $\%$ & $\times$ \\
\hline
\end{tabular}

were incorporated into SHOOTGRO 2.0 with some modifications. Most notably, SHOOTGRO 2.0 does not simulate root growth. Therefore, $\mathrm{N}$ and water uptake are distributed over the profile in proportion to the fraction of total available $\mathrm{N}$ or water within each soil layer, not as a function of the fraction of total root material found within each soil layer as is done by CERES-Wheat. Expanding SHOOTGRO 2.0 code to simulate $\mathrm{N}$ and water availability increased input requirements compared to SHOOTGRO 1.0 (Table 1).

\section{Seedling emergence submodel}

Seedling emergence is a function of heat unit accumulation, soil water availability, and seeding depth. Rates of germination and seedling elongation (Table 2) are assigned based on water-filled pore space (WFPS; Studdert, 1989). Water-filled pore space is calculated from soil water 


\section{TABLE 2}

Seed germination and seedling elongation rates for several broad categories of seedbed conditions

\begin{tabular}{|c|c|c|c|}
\hline $\begin{array}{l}\text { Seedbed } \\
\text { condition }\end{array}$ & $\begin{array}{l}\text { Water-filled } \\
\text { pore space }(\%)\end{array}$ & $\begin{array}{l}\text { Germination } \\
\text { time }\left(\text { GDD }{ }^{a}\right)\end{array}$ & $\begin{array}{l}\text { Elongation } \\
\text { rate }\left(\mathrm{mm} \mathrm{GGD}^{-1}\right)\end{array}$ \\
\hline Optimum & $>45$ & 80 & 0.50 \\
\hline Barely adequate & $35-45$ & 90 & 0.40 \\
\hline Dry & $25-35$ & 110 & 0.33 \\
\hline Planted in dust & $<25$ & - & - \\
\hline
\end{tabular}

${ }^{\mathrm{a}} \mathrm{GDD}=$ growing degree-day (base $0^{\circ} \mathrm{C}$ ).

content and bulk density of the soil layer into which seeds are planted. Number of GDD (base $0^{\circ} \mathrm{C}$ ) required for emergence (Table 2) is calculated at planting based on the current soil water content. As soil water availability changes because of precipitation or evaporation, rates of germination and seedling elongation are recalculated based on the new conditions.

Seedling emergence follows a normal distribution with a mean determined by seedbed conditions and planting depth. The user defines the variance for the distribution (default $\mathrm{CV}=20 \%$ ). Emergence is spread over a period of \pm 3 standard deviations. The fraction of seeds germinating is set to 0.85 of the planted seeds. To better describe plant-to-plant variation observed in the field, $n$ cohorts of plants are simulated (plants are grouped into cohorts based on time of emergence; $n \leq 6$, default $n=3$ ). Each cohort can have a maximum population of $1 / n$ of the germinated seeds. If seedlings do not emerge within $350 \mathrm{GDD}$ of planting [GDD are accumulated only when the soil has sufficient water content to allow imbibition, germination and elongation (i.e. WFPS $>25 \%$ )], they never emerge and the cohorts affected are truncated. Therefore, the number of individuals within each cohort varies from 0 to $1 / n$ with conditions. If conditions are too dry for germination to start (WFPS $<25 \%$ ), seeds remain inactive in the soil until conditions improve to levels supporting germination. All plants within a cohort are treated as though they have the median emergence time for that cohort. Maximum plant (plant with all possible tillers present) characteristics are multiplied by the number of individuals within the cohort with the given characteristics to obtain population parameters. Since development and growth processes occur at different times for each cohort, each cohort has a different level of resources available at each developmental stage. This attribute of the model allows the simulation to mimic variation among plants found within a stand (Benjamin and Hardwick, 1986). 


\section{Resource availability indices}

SHOOTGRO 2.0 calculates development and growth in response to availability of three of the resources necessary for plant growth and development: N, PAR, and water. Stress occurs when these resources are available at less than the optimum level. The 0 to 1 response functions developed for these factors have positive slopes. Since greater development and growth occurs as the scale increases from 0 to 1 , it was more logical to refer to the indices as indicators of resource availability than as levels of stress, which would imply a negative relationship.

The $\mathrm{N}$ availability index is based on available soil $\mathrm{N}$. The $\mathrm{N}$ balance assumes $2.0 \mathrm{mg} \mathrm{N} \mathrm{kg}^{-1}$ soil remains in the soil at all times (Godwin and Vlek, 1985) and is not available for plant uptake. The minimum available soil $\mathrm{N}$ concentration necessary for maximum growth was defined by the plateau in the whole plant dry matter production data of Campbell et al. (1977a,b). An available soil $\mathrm{N}$ concentration of $9.1 \mathrm{mg} \mathrm{N} \mathrm{kg} \mathrm{N}^{-1}$ soil was found sufficient for maximum growth. An available soil $\mathrm{N}$ concentration of $0 \mathrm{mg} \mathrm{N} \mathrm{kg}{ }^{-1}$ is assumed to permit no growth, with a linear increase in growth as available $\mathrm{N}$ increases from 0 to $9.1 \mathrm{mg} \mathrm{N} \mathrm{kg}^{-1}$ soil. Nitrogen recovered from senescing tissue (discussed later) is used by the crop before soil $\mathrm{N}$.

The soil water submodel is used to calculate availability of soil water. The 0 to 1 soil water availability index (SWAI) defined by the function of Rickman et al. (1975),

SWAI $=\frac{\log (\% \text { available water }+1)}{\log 101}$,

is used in SHOOTGRO 2.0.

The PAR availability index is defined as

INDEXL $=1.0-\left(\frac{\mathrm{LAI}}{3.5+\left(0.05975 * \mathrm{RR}_{\tilde{x}}\right)}\right)$,

where INDEXL is the 0 to 1 resource availability index for PAR, LAI is the leaf area index, and $\mathrm{RR}_{\bar{x}}$ is the 5 -day (current day plus 4 previous days) running average of daily total incoming PAR in $M J m^{-2} \mathrm{day}^{-1}$ (B. Klepper, unpublished data; Fig. 2).

The 5-day running average for each resource availability index is updated each day. Indices are multiplied to give a combined resource availability index which is used to limit development and growth from the maximum level (resource availability index 1.0) simulated in SHOOTGRO 1.0. The combined resource availability index is applied to each developing or growing organ. The product of all three resource indices impacts tiller 


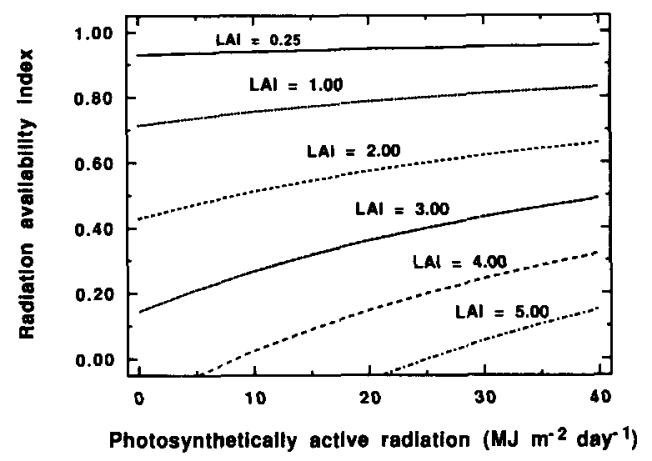

Fig. 2. Simulated relationship among leaf area index (LAI), 5-day running average of incoming photosynthetically active radiation, and radiation availability index in SHOOTGRO 2.0.

appearance; however, other processes are affected by availability of $\mathrm{N}$ and water only.

\section{Tiller frequency submodel}

In the model, tillers are identified by a naming system described by Klepper et al. (1983). Tillers appear at specific times relative to the Haun stage (Haun, 1973) of the main stem (Table 3A; Klepper et al., 1982). The Haun stage is a numerical scale describing phenological development based on the number of fully expanded leaves plus the ratio of the length of the expanding leaf compared to the length of the most recently fully expanded leaf. Since we assume specific tillers appear at specific times during the development of specific leaves, tiller appearance is defined in terms of phyllochrons. The phyllochron is measured in GDD, and is specific for a given emergence date and latitude (Baker et al., 1980). Time of tiller appearance is not affected by resource availability; but the specific tillers that appear are determined by resource availability.

Tillers are grouped into probability classes (Table 3A) to indicate their likelihood of appearing. Class 1 tillers are most likely to appear, while Class 3 tillers are least likely to appear. On the day the accumulation of GDD (since emergence) equals the phyllochron times the main stem Haun stage for the appearance of a specific tiller group, the relationship described in Fig. 3 is used to determine the fraction of plants (which have the necessary parent tiller) which produce tillers in probability Classes 1,2 and 3. For example, if the phyllochron for a planting is $100 \mathrm{GDD}^{\mathrm{ghyllochron}}{ }^{-1}$ and 330 GDD have accumulated since emergence, 3.3 (330 GDD/100 GDD phyllochron ${ }^{-1}$ ) phyllochrons have accumulated since emergence. From Table 3, we see tillers T2 and T00 can appear at that time. If the 


\section{TABLE 3}

Probability classes for tiller appearance (A) and abortion (B) in SHOOTGRO 2.0. Tiller groups which appear at the same time during the development of the plant are identified by the first order tiller which is a member of the group. Tiller T0 behaves differently from all other tillers and is handled in a separate manner, see text for details

\begin{tabular}{|c|c|c|c|c|}
\hline \multirow{2}{*}{$\begin{array}{l}\text { Tiller } \\
\text { group }\end{array}$} & \multirow{2}{*}{$\begin{array}{l}\text { Main stem } \\
\text { Haun stage } \\
\text { at appearance } \\
\text { of tiller group }\end{array}$} & \multicolumn{3}{|c|}{ Tiller probability class } \\
\hline & & 1 & 2 & 3. \\
\hline \multicolumn{5}{|c|}{ A. Tiller production } \\
\hline MS & 0.0 & MS & - & - \\
\hline 1 & 2.7 & $\mathrm{~T} 1^{\mathrm{a}}$ & - & - \\
\hline 2 & 3.3 & $\mathrm{~T} 2$ & - & T00 \\
\hline 3 & 4.0 & T3 & $\mathrm{T} 10$ & T01 \\
\hline 4 & 5.0 & $\mathrm{~T} 4, \mathrm{~T} 11, \mathrm{~T} 20$ & T30 & T000, T02, T100, T010 \\
\hline \multicolumn{5}{|c|}{ B. Tiller abortion } \\
\hline $\mathrm{MS}^{\mathrm{b}}$ & & - & - & - \\
\hline 0 & & - & T0 & - \\
\hline 1 & & T1 & - & - \\
\hline 2 & & $\mathbf{T} 2$ & - & T00 \\
\hline 3 & & - & $\mathrm{T} 3, \mathrm{~T} 10$ & $\mathrm{~T} 01$ \\
\hline 4 & & - & $\mathrm{T} 4, \mathrm{~T} 20$ & $\begin{array}{l}\text { T30, T11, T000, T02, T100, } \\
\text { T010 }\end{array}$ \\
\hline
\end{tabular}

a Nomenclature of Klepper et al. (1983).

${ }^{b}$ Main stem never aborted.

resource availability index (combined for PAR, $\mathrm{N}$ and water) is $0.70,70 \%$ of the plants would produce the Class 1 tillers, $40 \%$ would produce Class 2 tillers, and no plants would produce Class 3 tillers. For this example, T2

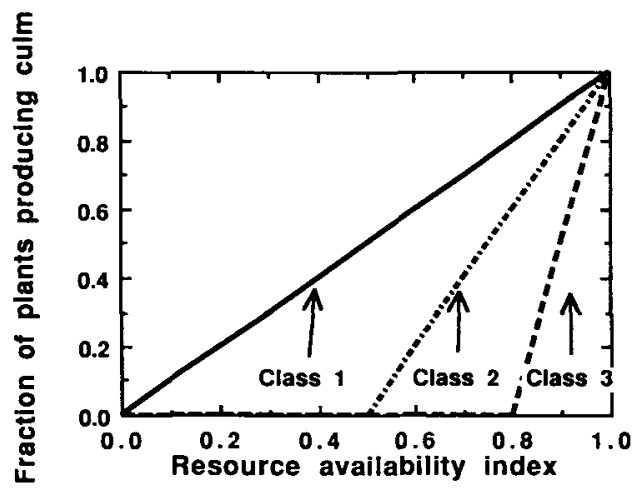

Fig. 3. Relationship between the combined resource availability index and class of tillers produced in SHOOTGRO 2.0. See Table 3 for list of tillers included in each probability class. 

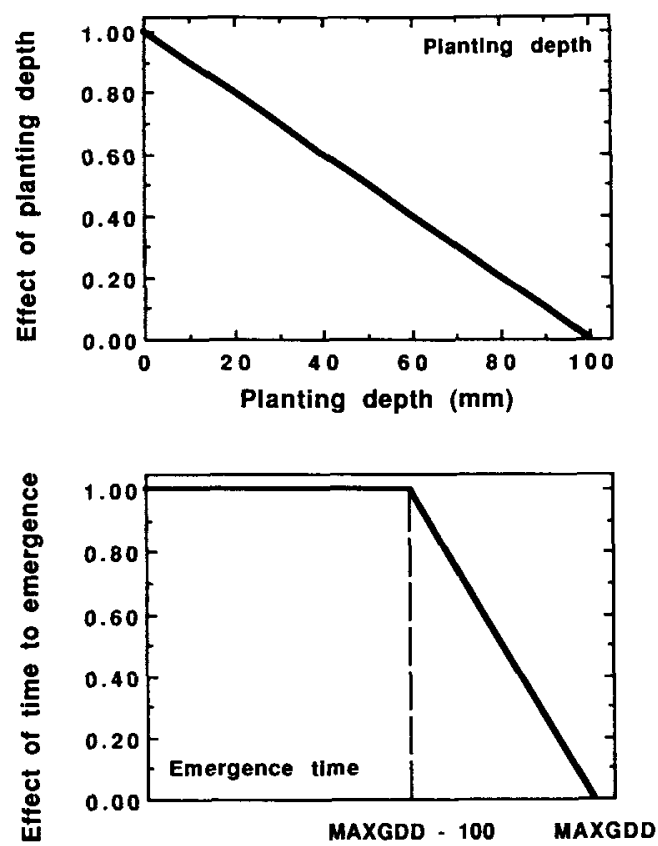

Time to emergence (GDD)

Fig. 4. Fraction of plants producing T0 (FT0) tillers based on planting depth and time to seedling emergence. MAXGDD $=$ GDDCON * PHYLLO, where GDDCON is the number of phyllochrons by which the median plant within a cohort must emerge to produce $\mathrm{T} 0$, (default $=2.4$ ) and PHYLLO is the phyllochron in growing degree-days.

(Class 1) would appear on $70 \%$ of the plants and no T00 tillers (Class 3 ) would appear.

Since the coleoptilar tiller (T0) in wheat behaves differently than other tillers (Peterson et al., 1982, 1989), calculation of T0 frequency is treated separately. We assume T0 frequency is a function of planting depth and time to seedling emergence. Since time to seedling emergence is a function of available soil water in the seedbed, T0 frequency is a function of soil water, not soil $\mathrm{N}$. Within each cohort, the effect of planting depth and time to seedling emergence (Fig. 4) is multiplied to determine the fraction of plants which produce T0. These relationships were derived from field experiments (Klepper, unpublished data).

\section{Leaf appearance submodel}

Leaf appearance is handled in the same manner as in the non-stressed plant model, SHOOTGRO 1.0. As was reported by Masle (1985), we assume resource availability has no affect on rate of leaf appearance. Bauer et al. (1988) also reported that neither the availability of $N$ nor water 
TABLE 4

Leaf growth rate factors for tillers in various dominance categories simulated in SHOOTGRO 2.0

\begin{tabular}{ll}
\hline Culm ID & $\begin{array}{l}\text { Growth rate } \\
\text { factor }\end{array}$ \\
\hline MS & 1.00 \\
T0, T1, T2, T00 & 0.95 \\
T3, T10, T01 & 0.90 \\
T4, T20, T02, T11, T100, T010, T000, T03 & 0.85 \\
\hline
\end{tabular}

affected developmental rate of spring wheat from emergence through heading.

\section{Leaf growth submodel}

SHOOTGRO produces leaf tissue by increasing the length and width of one leaf per culm at a time. As in SHOOTGRO 1.0, the maximum leaf length and width are defined as exponential functions of leaf number. These maximum dimensions are reduced for the less dominate tillers (Table 4). The base rate of leaf length and width extension are defined as the maximum length (or width) divided by the phyllochron in GDD. For example, the growth rate (length) for leaf 2 on the main stem (which has a maximum length of $116 \mathrm{~mm}$ in the model; McMaster et al., 1991) with a phyllochron of 110 GDD was $116 / 110$ or $1.05 \mathrm{~mm} \mathrm{GDD}^{-1}$. In SHOOTGRO 2.0, daily growth of leaf tissue is a product of the base leaf growth rate, degree-day accumulation, and the combined resource availability index. The resource availability index ( $\mathrm{N}$ and water) reduces the rate of growth to a value less than the maximum. Growth of an individual leaf ends when its age (in GDD) equals one phyllochron. Leaf weight is a constant multiple of the leaf area (specific leaf weight, default $45 \mathrm{~g} \mathrm{~m}^{-2}$; Morgan et al., 1990; Morgan and LeCain, 1991) which can be set by the user. Leaf sheath weight is assumed to be equal to 0.5 of the blade weight prior to development of the pseudo-stem (Zadoks stage 30; Zadoks et al., 1974). Weight of sheath material produced from the time of pseudo-stem development to the end of the simulation is equal to the blade weight. No length dimensions are computed for the sheath.

Availability of $\mathrm{N}$ determines the $\mathrm{N}$ content of new tissue. Nitrogen captured from senescing tissue is used first to satisfy new tissue $\mathrm{N}$ demand. Under conditions of adequate $\mathrm{N}\left(9.1 \mathrm{mg} \mathrm{N} \mathrm{kg} \mathrm{N}^{-1}\right.$ soil), new tissues are grown with an $\mathrm{N}$ concentration of $40 \mathrm{~g} \mathrm{~N} \mathrm{~kg}^{-1}$ dry weight. If available soil $\mathrm{N}$ falls below the adequate level, tissue is produced at a reduced $\mathrm{N}$ content. 
The $\mathrm{N}$ content of new tissue is based on the 5-day running average of available soil $\mathrm{N}$ as follows:

$[\mathrm{N}]_{\text {tissue }}=0.01+(0.03 * \mathrm{~N}$ availability index $)$.

The minimum tissue $\mathrm{N}$ concentration is set to $10 \mathrm{~g} \mathrm{~N} \mathrm{~kg}^{-1}$ dry weight. If total $\mathrm{N}$ availability is not sufficient to support the predicted level of growth (even at an $\mathrm{N}$ concentration of $10 \mathrm{~g} \mathrm{~N} \mathrm{~kg}^{-1}$ dry weight), dry matter production is reduced by an amount proportional to the shortfall in available soil N. Reduction in growth for each expanding organ is proportional to its demand for $\mathrm{N}$.

\section{Stem growth submodel}

Internode growth is modeled in a manner similar to that of leaves. The only difference is that maximum internode length is a power function of internode number.

\section{Leaf senescence submodel}

Non-stressed leaves (blades and sheaths) have a life span of 6.5 phyllochrons (Fig. 5). After that time, leaf tissue senesces over the span of one phyllochron. The rombined $\mathrm{N}$ and water resource availability indices are used to reduce the age at which senescence starts, resulting in an increase in the rate of tissue death. When tissue dies, the $\mathrm{N}$ content of senesced tissue is reduced to $10 \mathrm{~g} \mathrm{~N} \mathrm{~kg}^{-1}$ dry matter. The $\mathrm{N}$ released from senesced tissue is available for new tissue growth.

Leaf loss caused by low temperature during winter (dieback) is triggered if a total of 30 days within the two coldest months of the year have a mean air temperature $<0^{\circ} \mathrm{C}$ and the snow depth is less than the canopy height plus $25 \mathrm{~mm}$. When these criteria are met, all leaves, except the youngest leaf on each culm, are killed. This process can occur only once each season.

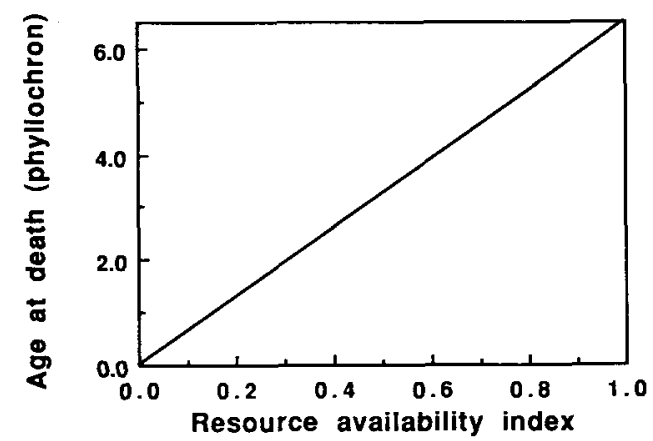

Fig. 5. Relationship used in SHOOTGRO 2.0 to change the rate of tissue senescence as resource availability index change. 


\section{Tiller abortion submodel}

Tillers are grouped (Table 3B) according to their prominence in the canopy (based on age and order). Less prominent tillers are more likely to abort as resources become limiting (Fig. 3). The relationships in Fig. 3 show the fraction of each class of tiller (Table 3B) that remains alive as the resource availability index ( $\mathrm{N}$ and water) changes during the simulation.

If the combined resource availability index becomes 0 (Fig. 5), a leaf dies at age zero. Therefore the leaf fails to appear. Failure of a leaf to appear is defined as death for the tiller. As in the non-stressed model (SHOOTGRO 1.0), tillers on which the fourth leaf has not appeared at jointing abort (Masle-Meynard, 1981; Masle, 1985; Rickman et al., 1985).

The model is written in ANSI standard FORTRAN77, executes on machines with DOS, UNIX, VM, or VMS operating systems, and is available on diskette or tape from the corresponding author.

\section{EVALUATION DATA SETS}

Two data sets were used to evaluate the model. The first source (McMaster and Smika, 1988) contained data on time of phenological stages of winter wheat for 19 site-years from 1977 to 1981 within the central Great Plains of the US. Data (McMaster, unpublished) on culm number and dry matter accumulation collected during the course of this study were also used. Data for nine randomly selected site-years (Albin, WY 1977-78, Akron, CO 1977-78 and 1978-79, Garden City, KS 1979-80, Mankato, KS 1977-78 and 1978-79, Paxton, NE 1977-78 and 1978-79, and Tribune, KS 1978-79) from the McMaster and Smika (1988) data set were used to evaluated SHOOTGRO 2.0.

The second data set was provided by Reginato and coworkers (Bauer et al., 1988; Hubbard et al., 1988; Major et al., 1988a,b; Reginato et al., 1988) from a 2-year study (1984 through 1986) at several sites in the US Great Plains: data from Mandan, ND, and Manhattan, KS, were selected for use in this evaluation because they contained the greatest detail on events occurring during vegetative development.

\section{RESULTS AND DISCUSSION}

SHOOTGRO 2.0 was designed with the purpose of incorporating current knowledge of winter wheat development into a simulation package. Several strengths of SHOOTGRO 2.0 are: (1) predicting the phyllochron; (2) predicting time of appearance and senescence of tillers and leaves; (3) predicting age and size of leaf blades and sheaths, and internodes on all 

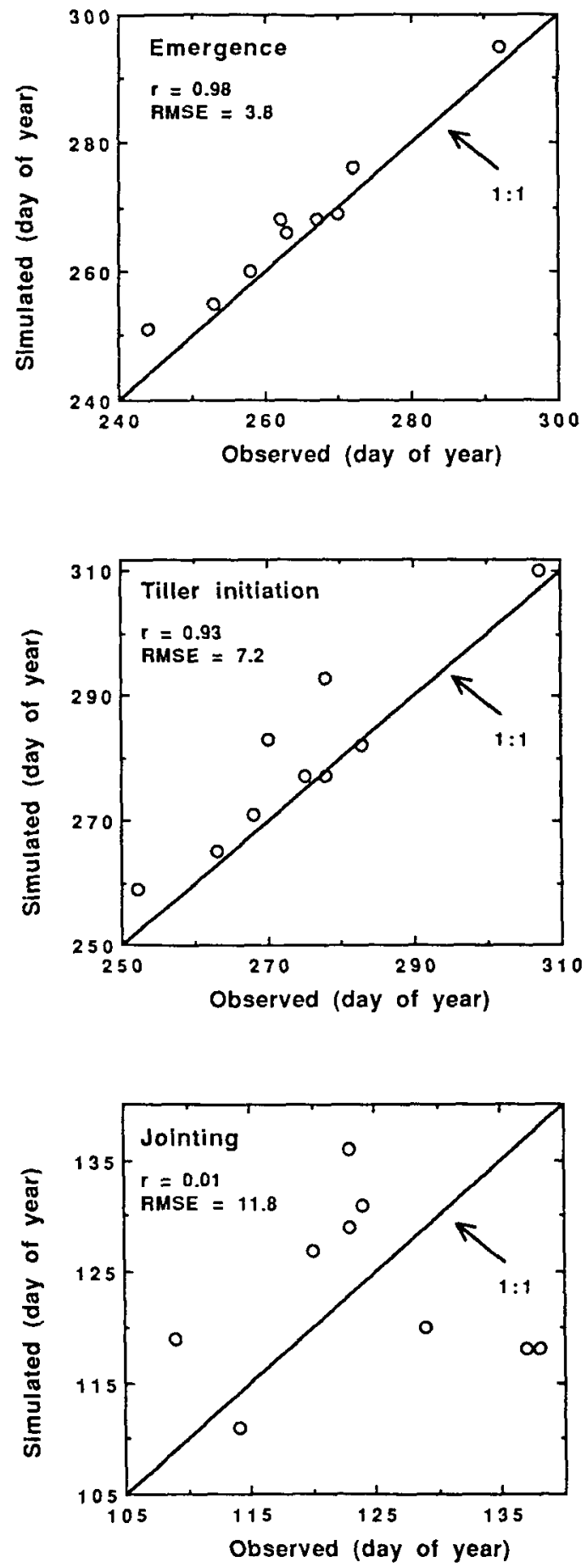

Fig. 6. Comparison of observed and predicted dates of emergence, tiller initiation, and jointing for nine sites-years described by McMaster and Smika (1988). Root mean square error (RMSE) is a measure of the degree of agreement between observed and simulated values (small values indicate good agreement). 
culms; and (4) providing a prediction of population variability by simulating development and growth of several cohorts of plants.

SHOOTGRO 2.0 tended to predict date of emergence and date of appearance of the first tiller slightly later (3.2 and 5.2 days, respectively, based on the average of the absolute residuals) than it actually occurred (Fig. 6) when compared to observed data from the nine site-years in the McMaster and Smika (1988) data set. Date of jointing was not accurately predicted. The algorithm used to predict date of jointing in SHOOTGRO 2.0 was from McMaster and Smika (1988), who indicated jointing was a difficult stage to predict with accuracy. The work of McMaster et al. (1992b) extended the SHOOTGRO 2.0 simulation to include spike growth and presented an algorithm which was more accurate for predicting time of jointing over a broad range of test data sets.
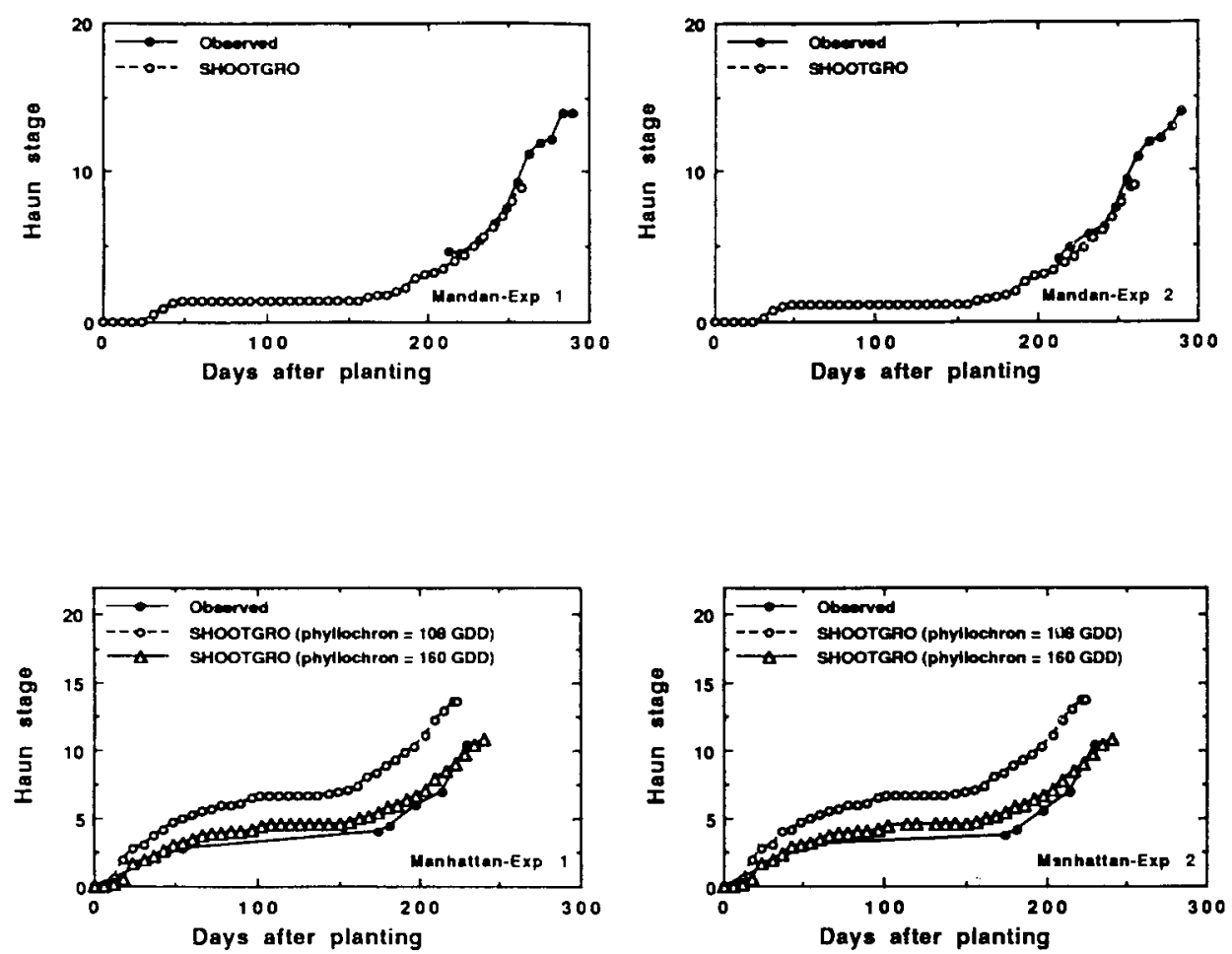

Fig. 7. Observed and predicted (SHOOTGRO 2.0) main stem Haun stage for two treatment combinations from the Mandan, ND, and Manhattan, KS, sites reported by Reginato et al. (1988). Experiments 1 and 2 at Mandan were the 0 and $100 \%$ irrigation, no fertilization treatment for the 1985-86 cropping season, respectively. Experiments 1 and 2 at Manhattan were the 55 and $160 \mathrm{~kg} \mathrm{~N} \mathrm{ha}^{-1}$, no-irrigation treatment for the 1984-85 cropping season, respectively. All data for the variety Colt. 
Simulation results of phenological stage were also compared to observed data from studies reported by Reginato et al. (1988) during the 1985-86 season at the Mandan and Manhattan sites (Fig. 7). Observed data and simulation inputs were for the variety Colt at both locations. Predicted main stem Haun stage for Cohort 2 at Mandan were very similar to observed data. However, observed and predicted data did not initially agree for the Manhattan site. The simulated and observed phyllochrons were very different (108 vs. $160 \mathrm{GDD}$, respectively) for this location. The observed phyllochron was much greater than normally reported (100 to 125 GDD) for winter wheat grown at a latitude of about $39^{\circ} \mathrm{N}$ and a planting date on 20 September (Baker et al., 1986; McMaster et al., 1992b). When

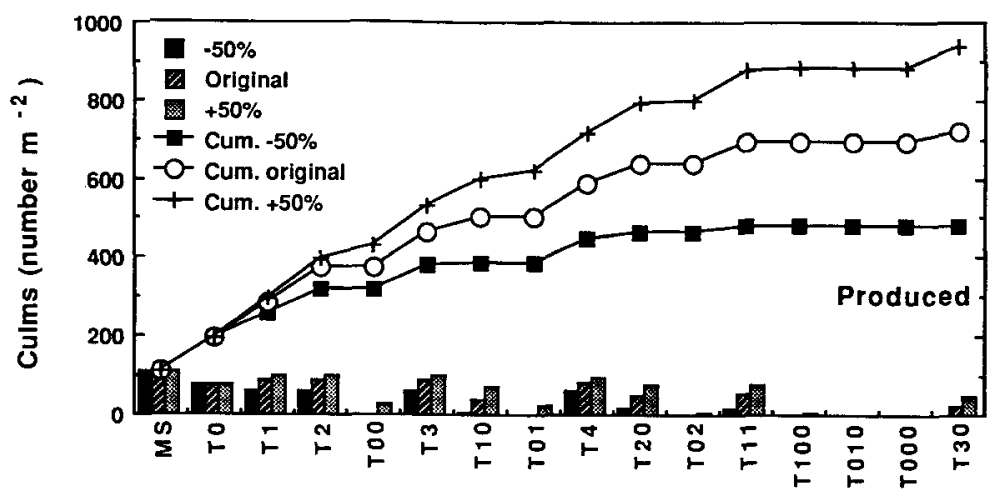

Culm identification

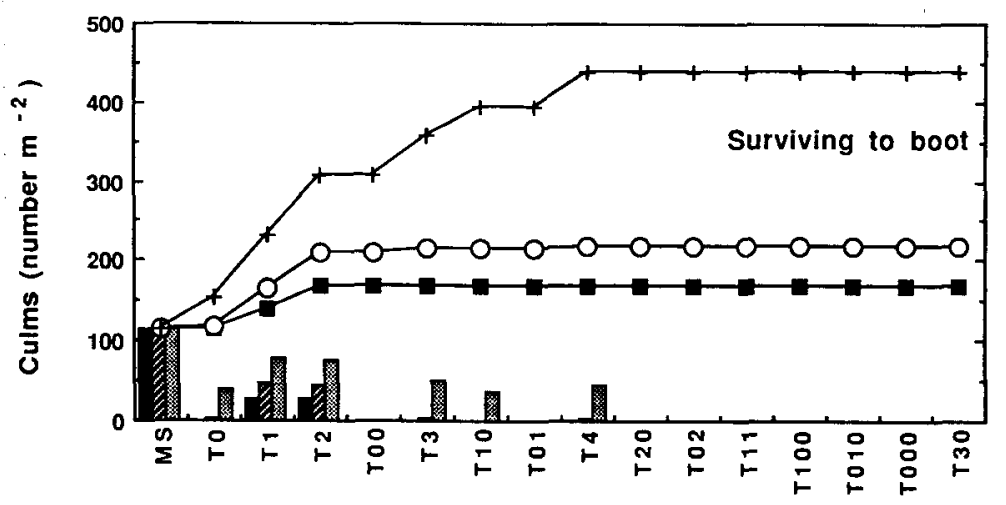

Culm identification

Fig. 8. Number of tillers produced and surviving to boot as affected by changing water available to the crop under the general conditions of the Akron, CO, 1977-78 crop season (McMaster and Smika, 1988). Bars indicate the number of each tiller produced or surviving, lines indicate cumulative number of all tillers produced or surviving. 


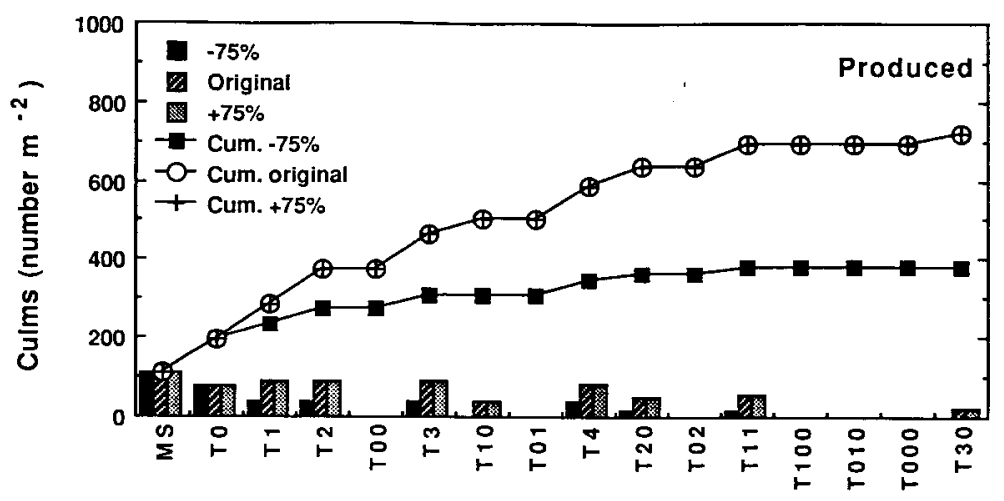

Culm identification

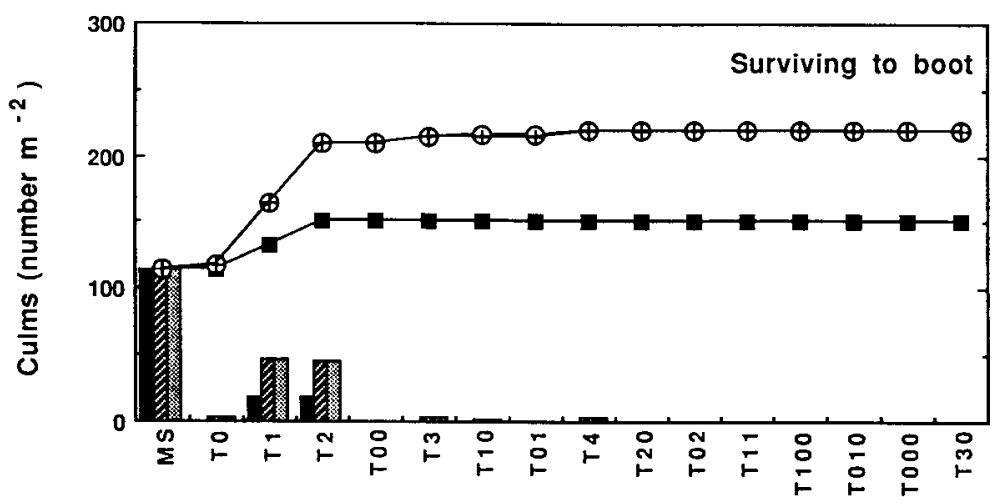

Culm identification

Fig. 9. Number of tillers produced and surviving to boot as affected by changing $\mathrm{N}$ available to the crop under the general conditions of the Akron, CO, 1977-78 crop season (McMaster and Smika, 1988). Bars indicate the number of each tiller produced or surviving, lines indicate cumulative number of all tillers produced or surviving.

the phyllochron was set to the observed value, the model prediction of main culm Haun stage agreed with the observed data. These results support two major assumptions in the SHOOTGRO models: first, the phyllochron is constant during vegetative development; and second, variation in $\mathrm{N}$ and water supply does not influence rate of vegetative development.

Data in Figs. 8 and 9 show the predicted plant response to increasing and decreasing water and $\mathrm{N}$ regimes (respectively) within the general conditions of the Akron 1977-78 growing season. For these comparisons, soil water and precipitation (Fig. 8) and soil $\mathrm{N}$ content (Fig. 9) were increased or decreased by 50 and $75 \%$, respectively. Tiller production 
increased as water and $\mathrm{N}$ was made more available. Class 3 tillers (Table 3; $\mathrm{T} 00, \mathrm{~T} 01, \mathrm{~T} 000, \mathrm{~T} 02, \mathrm{~T} 100$, and $\mathrm{T} 010$ ) were not produced except when additional water was made available to the simulated crop. Only Class 1 and 2 tillers survived to boot under all of the simulated conditions. Three culms (MS, T1, and T2) accounted for at least $94 \%$ of all culms surviving to boot under the conditions examined except when precipitation was increased $50 \%$ in which case, they accounted for $61 \%$ of the total number of culms. Under all conditions, tillers T0, T3, T4, and T10 accounted for the remaining tillers that survived. In the simulation, addition of $\mathrm{N}$ above that
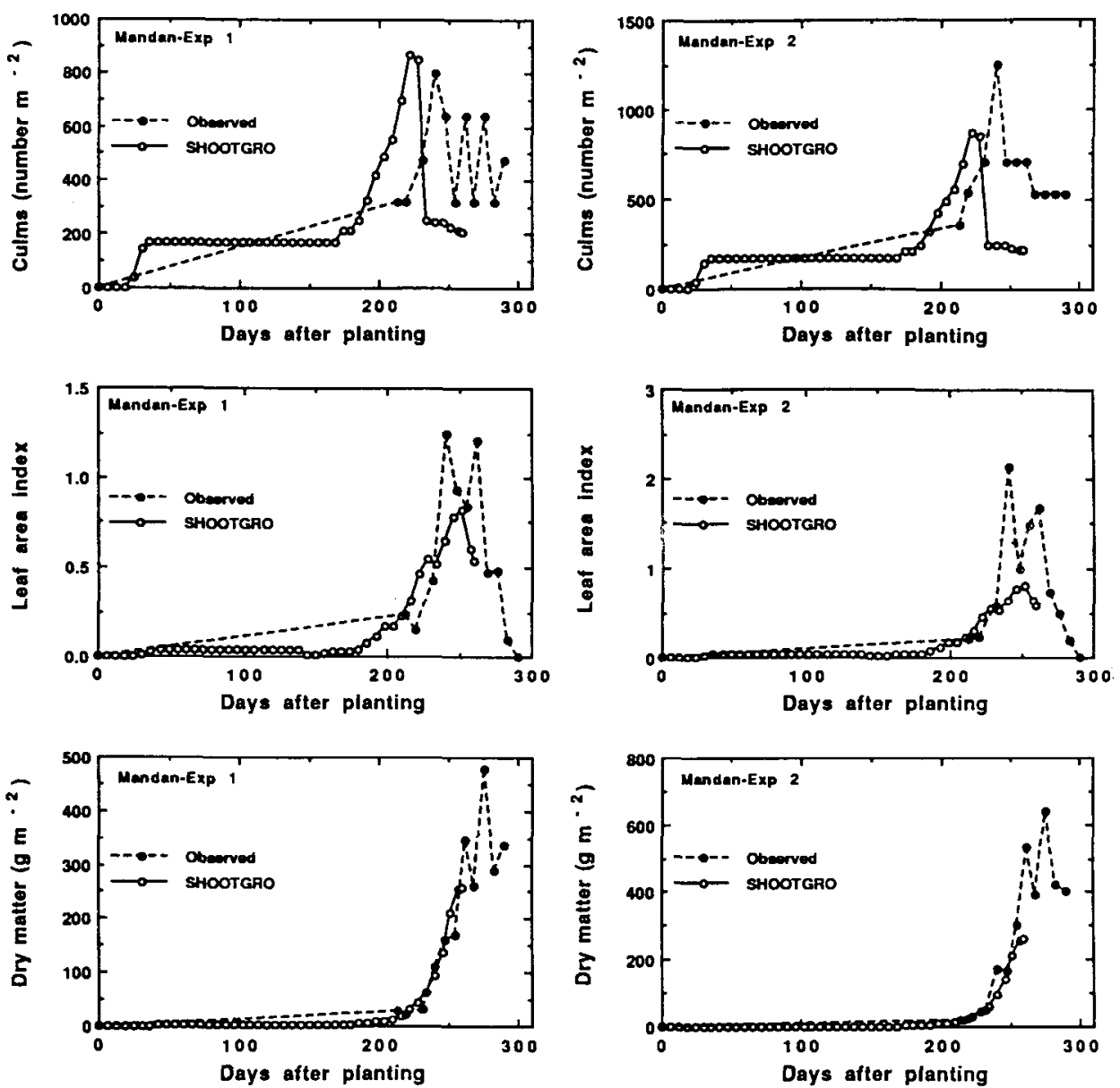

Fig. 10. Comparison of observed and predicted (SHOOTGRO 2.0) culm number, leaf area index, and dry matter production for two treatment combinations from the Mandan, ND, site reported by Reginato et al. (1988). See Fig. 7 for description of conditions for Experiments 1 and 2. 

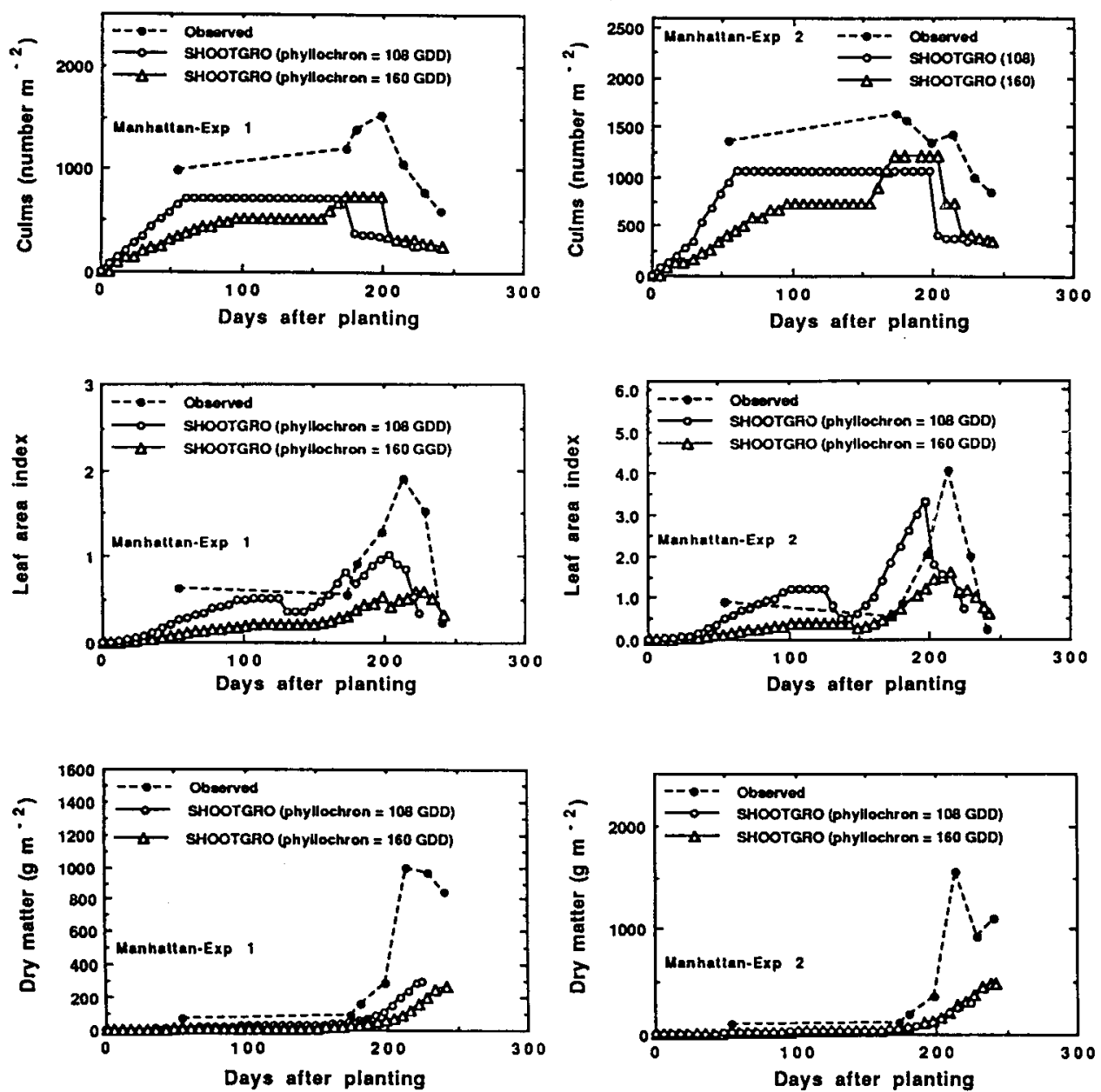

Fig. 11. Comparison of observed and predicted (SHOOTGRO 2.0) culm number, leaf area index, and dry matter production for two treatment combinations from the Manhattan, KS, site reported by Reginato et al. (1988). See Fig. 7 for description of conditions for Experiments 1 and 2.

available under the Akron 1977-78 conditions did not affect culm production or survival. These results emphasize the importance of water in wheat production in the central Great Plains and demonstrate how management strategy evaluation can be conducted with SHOOTGRO 2.0.

Comparisons of observed and simulated results for number of culms, leaf area index, and dry matter production for the Mandan and Manhattan sites described by Reginato et al. (1988) are presented in Figs. 10 and 11, respectively. Predicted culm numbers at boot were about $50 \%$ less than the number reported in the field (Fig. 10). However, field observations had 
considerable variation, especially in Experiment 1 at Mandan. Leaf area index was somewhat under-predicted, but again the field data were quite variable. Amount and pattern of simulated and observed dry matter production were similar.

Agreement between predicted and observed data for Manhattan was not good. SHOOTGRO 2.0 generally predicted fewer tillers than were observed in the field. Tiller number is a function of plant population, time and frequency of tiller appearance, and rate of tiller abortion. The observed plant populations at the seedling stage for Experiments 1 and 2 were 160 and 150 at Mandan, and 132 and 150 plants $\mathrm{m}^{-2}$ at Manhattan. The simulation predicted a plant population of 135 plants $\mathrm{m}^{-2}$. Unfortunately, the data sets did not provide information on the time of appearance and abortion of specific culms. The fact that maximum number of culms predicted was nearer the observed value than the number at boot, suggested the rate of tiller abortion in the simulation contributed more strongly to the discrepancy in tiller number than the rate of tiller production. The model is also limited to producing a maximum of 16 culms plant $^{-1}$, those which have the earliest opportunity to emerge (McMaster et al., 1991). Although limiting the number of simulated culm to 16 would have provided an ample number of culms (ca. $2560 \mathrm{culms} \mathrm{m}^{-2}$ ) at the plant populations used at the Mandan and Manhattan sites, failure of specific first order tillers ( $\mathrm{T} 0$ and $\mathrm{T} 1$ ) to emerge severely limits final culm densities. Six of the 16 culms simulated are a direct result of the appearance of $\mathrm{T} 0$; four culms result from $\mathrm{T} 1$. At 150 plants $\mathrm{m}^{-2}$, these tiller families account for 900 and 600 culms $\mathrm{m}^{-2}$, respectively. Our unpublished data indicate that culms not currently simulated by SHOOTGRO survived to maturity. Increasing the number of potential tillers and reducing the rate of tiller abortion in the simulation may improve the culm number, LAI and dry matter accumulation predictions.

The underprediction of culm number may have contributed to under prediction of LAI for Manhattan-Experiment 1. In Experiment 2 the magnitude of the observed and predicted LAI was similar, but were offset in time by about 2 weeks. Using the observed phyllochron (160 GDD) in the simulation improved the agreement in the timing of changes in LAI; however, the magnitude of the predicted LAI was reduced greatly. Again, failure to predict culm number correctly may have contributed to the failure to predict the quantity of dry matter observed in the field for the Manhattan experiments. The pattern of dry matter accumulation agreed well between predictions and observations.

The model provides a tool for predicting vegetative development and growth of the winter wheat canopy with individual culms identified and followed from emergence through boot. The simulated crop is divided into 
several cohorts based on time of seedling emergence. This attribute of the model allows output of frequency of occurrence of specific culms and leaves in the canopy. The model continues to be evaluated and expanded to include spike development (SPIKEGRO; McMaster et al., 1992a).

\section{REFERENCES}

Baker, C.K., Gallagher, J.N. and Monteith, J.L., 1980. Daylength change and leaf appearance in winter wheat. Plant Cell Environ., 3: 285-287.

Baker, J.T., Pinter, Jr., P.J., Reginato, R.J. and Kanemasu, E.T., 1986. Effects of temperature on leaf appearance in spring and winter wheat cultivars. Agron. J., 78: 605-613.

Bauer, A., Garcia, R., Kanemasu, E.T., Blad, B.L., Hatfield, J.L., Major, D.J., Reginato, R.J. and Hubbard, K.G., 1988. Effect of latitude on phenology of 'Colt' winter wheat. Agric. For. Meteorol., 44: 131-140.

Benjamin, L.R. and Hardwick, R.C., 1986. Sources of variation and measures of variability in even-aged stands of plants. Ann. Bot., 58: 757-778.

Brocklehurst, P.A., Moss, J.P. and Williams, W., 1978. Effects of irradiance and water supply on grain development in wheat. Ann. Appl. Biol., 90: 265-276.

Brown, P.L., 1971. Water use and soil water depletion by dryland wheat as affected by nitrogen fertilization. Agron. J., 63: 43-46.

Campbell, C.A., Cameron, D.R., Nicholaichuk, W. and Davidson, H.R., 1977a. Effects of fertilizer $\mathrm{N}$ and soil moisture on growth, $\mathrm{N}$ content and moisture use by spring wheat. Can. J. Soil Sci., 57: 289-310.

Campbell, C.A., Davidson, H.R. and Warder, F.G., 1977b. Effects of fertilizer N and soil moisture on yield, yield components, protein content and $\mathrm{N}$ accumulation in the aboveground parts of spring wheat. Can. J. Soil Sci., 57: 311-327.

Evans, L.T., Wardlaw, I.F. and Fischer, R.A., 1975. Wheat. In: L.T. Evans (Editor), Crop Physiology. Cambridge University Press, Cambridge, pp. 101-149.

Greenwood, E.A.N., 1976. Nitrogen stress in plants. Adv. Agron., 28: 1-35.

Godwin, D.C. and Vlek, P.L.G., 1985. Simulation of nitrogen dynamics in wheat cropping systems. In: W. Day and R.K. Atkin (Editors), Wheat Growth and Modeling. NATO, ASI Series A: Life Sciences Vol. 86. Plenum Press, New York, NY, pp. 311-332.

Haun, J.R., 1973. Visual quantification of wheat development. Agron. J., 65: 116-117.

Hooker, M.L., Mohiuddin, S.H. and Kanemasu, E.T., 1983. The effect of irrigation timing on yield and yield components of winter wheat. Can. J. Plant Sci., 63: 815-823.

Hubbard, K.G., Blad, B.L., Verma, S.B., Bauer, A., Hatfield, J.L., Kanemasu, E.T., Major, D.J. and Reginato, R.J., 1988. Monitoring the weather at five winter wheat experimental field sites. Agric. For. Meteorol., 44: 117-130.

Hunter, J.R. and Erickson, A.E., 1952. Relation of seed germination to soil moisture tension. Agron. J., 44: 107-109.

Klepper, B., Rickman, R.W. and Peterson, C.M., 1982. Quantitative characterization of vegetative development in small cereal grains. Agron. J., 74: 789-792.

Klepper, B., Rickman, R.W. and Belford, R.K., 1983. Leaf and tiller identification on wheat plants. Crop Sci., 23: 1002-1004.

Major, D.J., Blad, B.L., Bauer, A., Hatfield, J.L., Hubbard, K.G., Kanemasu, E.T. and Reginato, R.J., 1988a. Seasonal patterns of winter wheat phytomass as affected by water and nitrogen on the North American Great Plains. Agric. For. Meteorol., 44: 151-157.

Major, D.J., Blad, B.L., Bauer, A., Hatfield, J.L., Hubbard, K.G., Kanemasu, E.T. and 
Reginato, R.J., 1988b. Winter wheat grain yield response to water and nitrogen on the North American Great Plains. Agric. For. Meteorol., 44: 141-149.

Masle, J., 1985. Competition among tillers in winter wheat: Consequences for growth and development of the crop. In: W. Day and R.K. Atkin (Editors), Wheat Growth and Modeling. NATO, ASI Series A: Life Sciences Vol. 86. Plenum Press, New York, NY, pp. 33-54.

Masle-Meynard, J., 1981. Elaboration of the ear number of a winter wheat submitted to competition. Importance of a critical stage for a tiller, relevant to its elongation. Agronomie, 2: 17-23.

McMaster, G.S. and Smika, D.E., 1988. Estimation and evaluation of winter wheat phenology in the central Great Plains. Agric. For. Meteorol., 43: 1-18.

McMaster, G.S., Klepper, B., Rickman, R.W., Wilhelm, W.W. and Willis, W.O., 1991. Simulation of shoot vegetative development and growth of unstressed winter wheat. Ecol. Modelling, 53: 189-204.

McMaster, G S., Morgan, J.A. and Wilhelm, W.W., 1992a. Simulating winter wheat spike development and growth. Agric. For. Meteorol., 60: 193-220.

McMaster, G.S., Wilhelm, W.W. and Morgan, J.A., 1992b. Simulating winter wheat shoot apex development and growth. Developmental sequence and phenology submodel. J. Agric. Sci., Camb., 119: 1-12.

Morgan, J.A. and LeCain, D.R., 1991. Leaf gas exchange and related leaf traits among 15 winter wheat genotypes. Crop Sci., 31: 443-448.

Morgan, J.A., LeCain, D.R. and Wells, R., 1990. Semidwarfing genes concentrate photosynthetic machinery and affect leaf gas exchange in wheat. Crop Sci., 30: 602-608.

Peterson, C.M., Klepper, B. and Rickman, R.W., 1982. Tiller development at the coleoptilar node in winter wheat. Agron. J., 74: 781-784.

Peterson, C.M., Klepper, B. and Rickman, R.W., 1989. Seed reserves and seedling development in winter wheat. Agron. J., 81: 245-251.

Reginato, R.J., Hatfield, J.L., Bauer, A., Hubbard, K.G., Blad, B.L., Verma, S.B., Kanemasu, E.T. and Major, D.J., 1988. Winter wheat response to water and nitrogen in the North American Great Plains. Agric. For. Meteorol., 44: 105-116.

Rickman, R.W., Ramig, R.E. and Allmaras, R.R., 1975. Modeling dry matter accumulation in dryland winter wheat. Agron. J., 67: 283-289.

Rickman, R.W., Klepper, B. and Peterson, C.M., 1985. Wheat seedling growth and developmental response to incident photosynthetically active radiation. Agron. J., 77: 283-287.

Ritchie, J.T., 1972. Model for predicting evaporation from a row crop with incomplete cover. Water Resour. Res., 8: 1204-1213.

Ritchie, J.T., 1985. A user-oriented model of the soil water balance in wheat. In: W. Day and R.K. Atkin (Editors), Wheat Growth and Modeling. NATO, ASI Series A: Life Sciences Vol. 86. Plenum Press, New York, NY, pp. 293-305.

Sionit, N., Teare, I.D. and Kramer, P.J., 1980. Effect of repeated water stress on water status and growth of wheat. Physiol. Plant., 50: 11-15.

Studdert, G.A., 1989. Imbibition and germination of winter wheat as affected by water-filled pore space and temperature in three benchmark soils. M.S. Thesis, Univ. Nebraska, Lincoln, NE.

Zadoks, J.C., Chang, T.T. and Konzak, C.F., 1974. A decimal code for the growth stages of cereals. Weed Res., 14: 415-421. 